\title{
Augmented Chemiluminescence Response of Bronchoalveolar Lavage Cells in Calves Receiving Repeated Daily Sprayings of Ammonia Mist into the Nasal Cavities
}

\author{
Hideo MURATA \\ Shichinohe Research Unit, National Institute of Animal Health, Shichinohe, Aomori 039-25, Japan \\ (Received 13 February 1996/Accepted 19 November 1996)
}

ABSTRACT. The effect of ammonia inhalation on the luminol-dependent chemiluminescence response of bronchoalveolar lavage (BAL) cells was investigated in clinically normal calves receiving eight $\mathrm{m} l$ of ammonia water $(5,000 \mathrm{ppm})$ in the form of aerosol sprayed into the nasal cavities (four $\mathrm{m} l$ into each nostril) once a day for two weeks. The chemiluminescence level of the BAL cells was augmented following the sprayings of ammonia compared with prior to exposure. The level still remained high one week after the exposure was removed, but showed recovery after two weeks. — KEY wORDS: ammonia inhalation, BAL chemiluminescence, cattle.

J. Vet. Med.Sci. 59(2): 141-142, 1997

Ammonia is one of the most harmful pollutants in the air of animal confinement facilities. When inhaled, the gas dissolves in the liquid on the airway mucous membranes and causes respiratory tract damage such as impairment of pulmonary bacterial clearance in pigs [3]. Thus, ammonia is considered in several species to sensitize the animals to respiratory diseases by impairing the defense mechanisms of the respiratory tract against pathogens $[4,8,9]$. In cattle, however, the effect of ammonia on pulmonary immune function has been so far investigated little.

The purpose of this study was to preliminarily assess the effect of ammonia inhalation on bactericidal activity of pulmonary phagocytes in calves. For this purpose, the luminol-dependent chemiluminescence response of bronchoalveolar lavage cells was evaluated in clinically healthy calves receiving repeated sprayings of an ammonia mist into the nasal cavities.

Nine apparently healthy Holstein or Crossbred calves aged 6- to 10-months old (4 females and 5 castrated males), isolated in well ventilated pens, were used. The ammonia level in the air was $<10 \mathrm{ppm}$. The animals were randomly allotted into two groups, i.e., Ammonia-exposed (AE) and Control. Five calves in the AE group received an ammonia inhalation treatment as follows. The animals inhaled $8 \mathrm{ml}$ of ammonia water $(5,000 \mathrm{ppm})$ in the form of aerosol sprayed into the nasal cavities ( $4 \mathrm{ml}$ into each nostril) once a day at 09:00 with a portable atomizer (Canyon Corp., Japan) for one minute. The aerosol diameter was not measured. The treatment was repeated every day for two weeks. The four calves in the Control group received distilled water in the same manner. Bronchoalveolar lavage (BAL) was performed on the xylazine-sedated animals on five occasions at intervals of a week, i. e., before (Week 0), during (Weeks 1 and 2) and after (Weeks 3 and 4) the ammonia exposure, by instillation of a total of $300 \mathrm{ml}$ of sterile PBS solution ( $\mathrm{pH} 7.2$ ), using a polyethylene tube of $5 \mathrm{~mm}$ external and $3 \mathrm{~mm}$ internal diameter, inserted through the nostril into the right or left bronchiole regions. Following each infusion, the fluid was immediately withdrawn. Approximately 50 to 67 percent of the original volume introduced was recovered. The BAL cells were recovered from the lavage fluid by centrifugation and washed once with PBS. Then the cells were sorted by density gradient centrifugation(s.g. 1.077). The cells were comprised of 70 to $80 \%$ macrophages and 20 to $30 \%$ other mononuclear cells including lymphocytes and epithelial cells. Those cell percentages remained constant in each calf throughout the experimental period. The cells were counted and resuspended in Hanks' buffered salt solution (HBSS).

The chemiluminescence assay was performed by a modification of the previous method [7] as follows. Briefly, photon emission levels of the BAL cells $\left(4 \times 10^{4}\right)$ in response to a chemical stimulant (phorbol myristate acetate (PMA), Sigma Biochemical, St. Louis, U.S.A.; $1.6 \times 10^{-6}$ $\mathrm{M}$ at final concentration) were evaluated in the presence of luminol $(0.5 \mathrm{mg} / \mathrm{ml}$ at final concentration $)$ with a photoncounting luminescence analyzer (Berthold LUMAT LB9505C, Wildbad, Germany). The emission levels of the cells were represented as peak values (cpm). Statistical analysis of the values was performed by using Analysis of Variance (ANOVA). A level of $p<0.05$ was regarded as significant.

Table 1 shows PMA-induced chemiluminescence response of bovine BAL cells in the $\mathrm{AE}$ and Control groups. In the AE group, the chemiluminescence level remained unchanged at Week 1 but showed a significant increase at Week 2. The level was also significantly higher than that in the Control group. The level showed a further increase at Week 3, i. e., 1 week after the exposure was removed. At Week 4, the level showed a decrease and did not differ statistically from the initial value or the value in the Control group. The chemiluminescence level in the Control group showed a gradual rise during the experiment, but not significantly. The response is considered to be induced non-specifically following repeated BAL collections.

Additionally, based on routine clinical and hematological observations, the health condition of the calves was monitored throughout the experimental period. The animals developed no clinical abnormalities except for a dry and sporadic cough observed in the AE group just after the sprayings. No signs of being under stress or inflammation were detected on the blood and serum parameters examined.

In this study, repeated sprayings of ammonia mist into 
Table 1. PMA-elicited chemiluminescence response of bronchoalveolar lavage cells in the ammonia-exposed and control calves

\begin{tabular}{|c|c|c|c|c|c|}
\hline \multirow{3}{*}{$\begin{array}{l}\text { Group } \\
\text { (number of } \\
\text { animals) }\end{array}$} & \multicolumn{5}{|c|}{ Chemiluminescence level $\left(\log _{10} \mathrm{cpm}\right)$ at each sampling stage (week) } \\
\hline & \multirow{2}{*}{$\begin{array}{c}\text { before exposure } \\
\text { (Week 0) }\end{array}$} & \multicolumn{2}{|c|}{ during exposure ${ }^{a)}$} & \multicolumn{2}{|c|}{ after exposure } \\
\hline & & (Week 1) & (Week 2) & (Week 3) & (Week 4) \\
\hline $\begin{array}{l}\text { Ammonia- } \\
\text { exposed (5) }\end{array}$ & $\begin{array}{l}\left.4.08^{b}\right) \\
\pm 0.21\end{array}$ & $\begin{array}{c}4.11 \\
\pm 0.22\end{array}$ & $\begin{array}{l}4.76^{\mathrm{c}, \mathrm{d})} \\
\pm 0.26\end{array}$ & $\begin{array}{l}5.04^{\mathrm{c})} \\
\pm 0.72\end{array}$ & $\begin{array}{c}4.63 \\
\pm 0.34\end{array}$ \\
\hline $\begin{array}{l}\text { Control } \\
\text { (4) }\end{array}$ & $\begin{array}{c}4.05 \\
\pm 0.10\end{array}$ & $\begin{array}{c}4.11 \\
\pm 0.27\end{array}$ & $\begin{array}{l}4.28^{\mathrm{d})} \\
\pm 0.34\end{array}$ & $\begin{array}{r}4.39 \\
\pm 0.46\end{array}$ & $\begin{array}{c}4.63 \\
\pm 0.44\end{array}$ \\
\hline
\end{tabular}

a) Ammonia exposure was performed daily for the first two weeks.

b) Values represent mean \pm standard deviation.

c) The mean is significantly different $(\mathrm{p}<0.05)$ from the initial value before exposure.

d) Figures having same superscripts between the ammonia-exposed and control groups differ significantly $(\mathrm{p}<0.05)$.

the nasal cavities enhanced the chemiluminescence response, a bactericidal index, of BAL phagocytes in calves. In humans and laboratory animals, chemiluminescence of BAL cells is introduced as a valuable parameter to assess the events in the inflammatory process and/or immune reaction in the lungs $[1,5]$. The present results, as observed in the silica-inhaled rats [1], clearly demonstrate the inflammatory cell reaction in the lungs due to ammonia inhalation. Ammonia is known in poultry to cause changes in respiratory epithelium including loss of cilia and increased mucus secretion [6]. When impaired, the epithelial cells can produce inflammation-related cytokines which immunomodulate inflammatory cells including alveolar macrophages [2]. The mechanism of the BAL cell activation in this study is unknown but might have been induced in response to cytokines released from the epithelial cells impaired by ammonia exposure. Interestingly, the BAL cell activation was still evident at Week 3, i. e., 1 week after the ammonia exposure was removed. The existence of inflammation was not confirmed on clinico-hematological parameters but the lingering cell activation is considered as a prolonged inflammatory cell response in the lungs.

It must be noted that the present ammonia treatment was different in intensity and duration from the field ammonia exposure, i. e., probably much milder, but continuous exposure in the form of gas, in animal confinement facilities. It is yet unknown as to how animals would develop pulmonary cell responses in such cases. The present knowledge, however, seems valuable, at least in part, toward elucidating the role of pulmonary inflammatory cells in calves exposed to ammonia in further experimental and field investigations.

ACKNOWLEDGEMENTS. The author is grateful to Drs. T. Asano, M. Kamimura, S. Tanaka and M. Yasuda for technical assistance.

\section{REFERENCES}

1. Antonini, J. M., Van Dyke, K., Ye, Z.-G., DiMatto, M., and Reasor, M. J. 1994. Envir. Health Perspec. 102 (Suppl. 10): 37-42.

2. Denburg, J. A., Gauldie, J., Dolovich, J., Ohtoshi, T., Cox, G., and Jordana, M. 1991. Int. Arch. Allergy Appl. Immunol. 94: 127-132.

3. Drummond, J. G., Curtis, S. E., Meyer, R. C., Simon, J., and Norton, H. W. 1981. Am. J. Vet. Res. 42: 963-968.

4. Gustin, P., Urbain, B., Ansay, M., and Nicks, B. 1991. Ann. Med. Vet. 135: 417-422.

5. Halme, M., Maasilta, P., Repo, H., Ristola, M., Taskinen, E., Mattson, K., and Cantell, K. 1995. Int. J. Rad. Oncol. Biol. Physics 31: 93-101.

6. Julian, R. J. 1991. pp. 863-884. In: Diseases of Poultry, 9th ed.(Calnek, B. W., Barnes, H. J., Beard, C. W., Reid. W. M., and Yoder, H. W. Jr. eds.), Iowa State Univ. Press, Ames.

7. Murata, H. and Imada, T. 1996. J. Vet. Med. Sci. 58: 363364.

8. Targowski, S. P., Klucinski, W., Babiker, S., and Nonnecke, B. J. 1984. Infect. Immun. 43: 289-293.

9. Urbain, B., Gustin, P., Prouvost, J.-F., and Ansay, M. 1994. Am.J.Vet.Res. 55: 1335-1341. 